\title{
On the Survival Dilemma of Modern Individuals in Kafka's The Judgement
}

\begin{abstract}
Xiufan Dai ${ }^{1,}$
${ }^{1}$ Hunan Normal University
${ }^{*} 1642898691 @ q q . c o m$

ABSTRACT

Through such means as metaphor and symbolization, Kafka gave his novel The Judgment (Das Urteil) multiple meanings, giving it the nature of a modern allegorical novel. This work contains the characteristics of multiple referents and complex meanings, thus providing readers with the possibility to interpret it in multiple dimensions and from multiple perspectives. In addition, in this novel, such propositions as the expression of religious meanings, the perspective of the image of how father and son get along, and the prominence of modernity under tragic circumstances have constructed the spiritual world behind this work. Readers can dig out the deep meanings in this work based on their own life experience and aesthetic experience, thus conducting further research on Kafka and existential literature.
\end{abstract}

\section{Keywords: Kafka, The Judgement (Das Urteil), Modernity Dilemma, Existentialism}

\section{INTRODUCTION}

So far, many scholars have carried out analysis and research on Kafka and the novel The Judgement from different perspectives. For example, some researcher analyzed the text from the perspective of psychoanalysis, taking the psychology of the writer himself as the research subject; some researcher discussed personal rebellion in an alienated society from the perspective of Kafka's existential ethics; while other researchers studied Kafka's thoughts and works from a religious point of view.The research on Kafka is mainly summarized into the following three aspects. First, the life and text of Kafka. For example, the scholar who first noticed Kafka was Professor Ergen Born, whose Franz Kafka's Influence in His Life recorded Kafka's experience in detail. After Kafka's death, his friend Brod wrote The Biography of Kafka, which narrated Kafka's life for us; second, the study of Kafka's basic thoughts and themes. For example, such books as Kafka's Faith and Doctrines and Despair and Liberation in Kafka's Works, which his friend Brod wrote. Third, the study of Kafka's existential ethics system. For example, What Kafka Said to Me written by Janosh shows Kafka's insights in philosophy, aesthetics, and ethics in the form of "conversations". They can clarify certain aspects of the text, yet they fail to provide a penetrating explanation of the work itself. Starting from text analysis, this paper intends to explain the alienation of human nature and the nihilism of life under the capitalist social background shown in the novel, so as to provide a reference for the survival dilemma of modern humans.

\section{TRACING OF RELIGIOUS SENTIMENT}

As a writer of Jewish descent, the religious sentiment in Kafka's spiritual world had always been hard to erase. Moreover, he is good at infiltrating the devout faith of Jewish believers into his works. For example, in Midnight Silence, he said: "To live, one must have faith. What is faith? It means to believe in the reasonable inner links of all things and all times, to believe that life as a whole will last for ever, and to believe both the closest and the farthest things." This provides a broad religious and cultural background for our in-depth analysis of the novel The Judgment -- Kafka's religious sense of original sin and self-consciousness were extremely deep.

The superficial narrative of The Judgment is rather simple and absurd. At the beginning of the novel, Georg, a young businessman, wrote to his friend in Russia, telling him that he was going to get married, and hoped that he would come to the wedding. Then he went to his father's room, informed him that he was about to get married and that he wrote to invite his friend. His father rudely blamed him for deceiving his friend all the time, and thought that getting married was a betrayal of his mother who had just passed away, and blamed him for being a selfish and inhuman person. This friend and his 
fiancee were actually arranged by his father deliberately. His father seemed to control all of Georg's fortunes, leaving him nowhere to escape. In the end, the father sentenced his son to throw himself into the river, and the son rushed out of the house like a machine without any sense of resistance and jumped into the river from the bridge. Behind the story, we can further explore the relationship model with the Christ archetype. The infinite admiration, fear, inferiority, self-blame, and resignation that Georg the protagonist showed in front of his father is an almost absurd consciousness of surrender. At its root, it is an extension of religious meanings. Taking the image of the father as an example, the father was "mysterious" and insisted on living in isolation, living in a dark room that could only be reached through a narrow aisle; his behavior was often unexpected. He would suddenly lift off the quilt tightly covered by his son, stand upright on the bed, and lightly support the ceiling with one hand; even if he was already an old man with poor ability of self-care, gray-haired and anile, he still insisted in using the last bit of effort to deal with his son, knowing everything about Georg's correspondence with his friend, as well as his love and marriage. From the perspective of ordinary people, we can never give such an image and such a father a reasonable explanation anyway. But from a religious perspective, his father was a "god" in Georg's world, and his existence was a symbol of the supreme theocracy. Theocracy has never been used to support and maintain rational value standards, but it's an irrational symbol that does not allow questioning and resistance. In the Western world of knowledge, people always have inherent evil in front of God. According to Christianity, "only by worshipping God, forgiving, and having fraternity can people wash away their sins and ascend to heaven on the Judgment Day." The same pattern of thinking can be projected into the relationship between Georg and his father. Georg could only achieve selfsalvation by giving up his human desires, swallowing insults, and going through hardships. Therefore, at the end of the novel, when he faced his father's most cruel and ruthless judgement, he could not mobilize the rebellious genes in his body to fight and survive. Instead, he ran to death without hesitation in order to obtain the ultimate redemption. This implies the logic system of "original sin-punishment-salvation" derived from religions. To a certain extent, Georg's deep religious sentiment drove him to continuously fall into a downward spiral.

\section{THE PERSPECTIVE OF THE FATHER- SON RELATIONSHIP}

With poorly articulated language, caricature irony, and an absurd writing style, Kafka portrayed the father's image in Georg's mind. His aloof image had always shrouded everything about Georg like a shadow. His father was tyrannical, indifferent and brutal, but Georg still served him full of self-blame and guilt, doing all he could to show his respect, love and obedience, lest he could not be taken good care of. However, his father was not even slightly moved by these things. This harsh mind control had actually led to a pathological attachment to his father.

Georg's attitude towards his father was with a sentiment of original sin, which was an inherent guilt and self-blame of the "son". For example, when he saw his father's unclean underwear, he blamed himself for not taking good care of him. He believed that it should be his duty to remind his father to change his underwear frequently. Without discussing with his fiancée, he was determined to bring his father into his new home in the future; when his father accused him of being selfish and hypocritical without any reason, what he was thinking about was what if his father fell and hurt his body. He even felt deeply disturbed for not telling his father that he wrote a letter to his good friend from childhood who was living in a foreign country.... This kind of unequal love and unreasonable relationship that doesn't make sense according to common sense is similarly reflected in To My Father. He confided that under his father's tyrant rule, he lived trembling and with guilt like a stranger. His father kidnapped Kafka psychologically and thoroughly. But in his subconscious, he was filled with complex emotions of disgust, dislike, admiration, and attachment to his father. I think this is similar to the "Stockholm complex" and "hostage complex" in psychology.

The "father" in the novel is the character that Kafka focused on, and this archetype image is the incarnation of the "holy father" in the earthly world. In the Old Testament: Genesis, Jehovah the God is a supreme, ubiquitous, omnipotent god who created and dominates everything, and has the ultimate power of people's life and death. He is both majestic and kind, indifferent and compassionate, he loves his people, and is formidable Father. As his people, humans must fear God, obey His way, love Him, serve Him with all their heart and soul, and obey His commandments and decrees. When we compare the "Father" in the Bible with the "father" of Georg, we feel that the two are quite different. The father in the text has greatly lost the original divinity of the "Holy Father", and has become strange, brutal and absurd. In the novel, the room where the father lives is gloomy and mysterious, and the description of the father's image is also vague. The author dispelled the sacred halo of this archetype image mainly through realistic and ironic detailed descriptions, as well as Georg's intermittent description of his subjective feelings about the "father". In the end, the author ended the novel with the exaggerated and absurd plot of the father's sentence of his son to commit suicide, making the father's image full of absurdity. The lofty, majestic, and respectable image of the "Holy Father" in his son's mind thus disappeared, leaving only a kind of contempt and disgust. 
The image of God in the hearts of human beings implied in the ext is full of corruption, viciousness, and oppression like the father. For the future of human nature and human society, it is inevitable to have a feeling of pessimism and disappointment. Kafka expressed a strong sense of absurdity and a deep fear, and people realized the confusion of divinity in the reality. [1]

In this contest between the father and the son, the image of the father becomes more and more authoritative, and the image of the son becomes weaker and weaker. Kafka saw painfully that people had to compromise with anonymous authorities who opposed them in their lives. These anonymous authorities are "irrational authorities", not possessing super-high moral standards and outstanding achievements. Thus we can understand why Kafka named this novel The Judgment. In the novel, the son's obedience to his father is not rational obedience, but forced obedience under suppression. Judgment is also a blind and irrational judgment. It not only influences people's way of life, but also controls people's spiritual life. As a result, people's thinking has become irrational.

The era that Kafka lived in was the transitional period between the old and the new. The bourgeois republic was established, but the old contradictions were not completely resolved, and various new social contradictions emerged one after another, causing social turmoil. The father-son struggle represents the struggle between two different cultural concepts or the different values of two opposing classes. In the novel, the father's judgment on the son was the inevitable result of the son's struggle against the father's authority and his failure to escape the powerful shadow of the father. The most extreme manifestation of this irrational authority is like Georg in the text. His freedom was in the control of his father, and he chose to die as soon as his father gave such an order. This relationship alludes to the psychological barriers caused by "irrational authority" to modern people, and it is also a phenomenon of self-alienation that modern people show under the pressure of survival.

\section{THE SADNESS OF MODERNITY}

The Judgment was a love letter from Kafka to Miss Felice Bauer who he has just met. Kafka longed to have a sincere and warm love. He was attached to and fascinated by women. However, after three engagement, he canceled his marriage three times, showing a sickly fear of marriage. Behind this ambivalence is the sadness projected by modernity on humans, and the deep alienation of human existence.

The direct cause of this situation is Kafka's tense relationship with his father. In The Judgment, the father scolded his son for hesitating too long in marriage and failed to let his mother attend his wedding before her death; on the other hand, he satirized the extremely sacred love in his son's eyes: "Just because she lifted up her dress, you approached her and sought satisfaction in her without any hamper. You shamefully ruined our memory of your mother."[2]The father laughed that his son wanted to get married only to satisfy his sexual desire, and that his fiancee was just a frivolous woman who would seduce men... this can be projected to the relationship between Kafka and his father. His father had been dispelling the the hope and the good part of human desires in Kafka at every single moment. It is hard to imagine that people in such an environment will intervene in life with a proactive attitude, the sense of human life is gone, and people can't find a single reason to continue existing.

He originally loved life, but he shrank his desires for life in a manner similar to masochism, such as his desires for food (vegetarian), sex, friends, etc. This paradoxical way of thinking constitutes Kafka's dual personality and complex, painful, and indescribable inner experience. In The Judgement, he summarized his friendships in this way: "I can't tailor myself to another person, a person who may be more suitable for his friendship than the real person I am." [3]This is also a sense of powerlessness when people are forced to move towards alienation under modernity. After all, our appearance is different from the expectation of the operation of society. Throughout their entire lives, people cannot reach that. As a result, people's living conditions are approaching loneliness, death and ultimate meaninglessness, and they are full of mental confusion about themselves.

In addition, writing is also one of the reasons why Kafka has both yearning and fear of marriage. Kafka let out his inner pain and indescribable fear through writing. He was afraid that he would have to give up his beloved writing after getting married. For him, writing was a kind of escape and salvation from real life. He once said: "I often think that the ideal way of life is to stay in the innermost room of a spacious, closed cellar with a pen, papers and a lamp. While I am a jackdaw living in the cellar, not sleeping during the nighttime, highly spiritually describing the meaning of my dreamlike inner life, so that all other things become secondary." [4]At death-like nights, in the frozen inner ocean, what surrounded him was only "fear, which was entwined with me tightly." This passage is also an expression full of modernity. In the modern society where space-time links are everywhere, people long to hide themselves in a corner in the world, escaping from noise and loneliness, judgement at the value level, bullying, plundering and oppression, yet that doesn't exist, what we are facing is but "structural suffering" in a form of radiation, and the only way of salvation and liberation is death.

The era that Kafka lived in was the transitional period between the old and the new. The bourgeois republic was established, but the old contradictions were not completely resolved, and various new social contradictions emerged one after another, causing social 
turmoil. The father-son struggle represents the struggle between two different cultural concepts or the different values of two opposing classes. In the novel, the father's judgment on the son was the inevitable result of the son's struggle against the father's authority and his failure to escape the powerful shadow of the father. The most extreme manifestation of this irrational authority is like Georg in the text. His freedom was in the control of his father, and he chose to die as soon as his father gave such an order. This relationship alludes to the psychological barriers caused by "irrational authority" to modern people, and it is also a phenomenon of self-alienation that modern people show under the pressure of survival.

When we connect the novel with modern society, we can naturally connect with the spiritual crisis facing human beings today, consumerism and the state of human existence, alienation, as well as other practical issues. Nowadays, we're all in the spiritual crisis of modern society. With the intensification of the spiritual crisis, we have a universal, serious, fundamental and lasting suspicion of ourselves. People try to fill the emptiness deep in their hearts by infinitely satisfying their expanding material desires. They assume that what the external world preaches is the best way of life, thus they gradually lose their ability to reflect and judge, and fall into the whirlpool of the times. With the development of science and technology and the continuous progress of society, people's original state of existence has undergone tremendous changes. On the one hand, people are fascinated by the modern society they have transformed, and on the other hand, their beliefs have collapsed. This traps them in shackles forever, pushing them step by step toward the abyss of alienation. The research on Kafka can help us reflect on the current living conditions of human beings, and reflect on the pessimism and nihilism problems faced by humans. His works are a demonstration of the plight of modern human existence. They are a kind of psychological reality with profound realistic meanings and humanistic care.

\section{CONCLUSION}

To some extent, the father's judgment is actually Georg's own judgment, and it is also a realistic judgment when an individual in a dilemma cannot find a way out. At the same time, Kafka made efforts on the path of salvation, exploring how individuals can find the possibility of survival under absurd living conditions, that is, Kafka's existential ideal. He advocated that people should pay attention to themselves, create themselves, and reshape themselves in reality; that the origin of the world is an "irrational emotional experience", and that we have the right to choose and pursue freedom. Georg couldn't accept his father's control, so he escaped, which was a free choice. Even his suicide in the end was the best way to gain spiritual freedom in Georg's view. When evaluating Kafka, Auden, the British poet said: "Kafka is very important to us, because his dilemma is the dilemma of modern people." Nowadays, there is a rapid process of modernization and industrialization, and science and technology are updating with each passing day. Faced with the pressure in all directions and the emptiness shown in life, humanity is gradually alienated. In this era, we also feel deep fear and ubiquitous anxiety. Therefore, what Kafka wrote has transcended a specific historical situation. He expressed the shared inner feelings of modern mankind in the form of literature, and gave us spiritual shock and enlightenment[5].

\section{REFERENCES}

[1] Zhao Shan Kui. From the feeling of absurdity to the ways of death_Kafka's way of existence[J] . The east forum. 2000 .

[2] Franz Kafka . A collection of Kafka's short stories[M] . Shanghai : Shanghai Translation Publishing House. 2012.

[3] Franz Kafka . A collection of Kafka's short stories[M] . Shanghai : Shanghai Translation Publishing House. 2012.

[4] Lv Sha Dong. The awe and hatred of the cave bird-Reconstruction of the meaning of Kafka's Judgment[J] . Guangxi : Guangxi Academy of Social Sciences. 2005.

[5] Ye Ron . An analysis of Kafka's existential ethics[D]. 2017. 